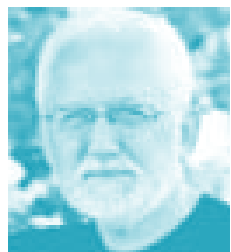

Arne Teige

er psykiatrisk sykepleier

ved Førde sentralsykehus.

I denne serien på 10 artikler gir han en grunnleggende innføring i de vanligste forskningsmetodene. Serien «Det metodiske hiørnet» skal sette leserne istand til kritisk å vurdere nyere forskning i sitt arbeid.

\title{
Om grafiske figurer og tabeller
}

Jeg har beskrevet hvordan vi kan sammenfatte data ved hjelp av ulike mål for gjennomsnitt og variabilitet. Tabeller og grafiske figurer kan hjelpe oss med det samme.

$\mathbf{T}$ abeller og grafiske figurer er også viktige hjelpemidler i forberedelsen til de statistiske analysene. Datasettet nedenfor er «masse tall» som det er vanskelig å få oversikt over. Dette til tross for at datasettet har få (48) verdier.

Tabell 1.

Luteiniserende hormon (le/L) målt hos NN hvert 10. minutt

\begin{tabular}{lll|l|l|l|l|l|l|l|l|l|ll|ll}
1 & 2.4 & 7 & 2.3 & 13 & 2.2 & 19 & 2.2 & 25 & 2.3 & 31 & 2.7 & 37 & 1.5 & 43 & 3.1
\end{tabular} \begin{tabular}{llll|ll|ll|lll|ll|ll|ll}
2 & 2.4 & 8 & 2.3 & 14 & 1.8 & 20 & 1.9 & 26 & 2.0 & 32 & 2.3 & 38 & 1.4 & 44 & 2.6
\end{tabular} \begin{tabular}{lllllllll|lllllllll}
3 & 2.4 & 9 & 2.5 & 15 & 3.2 & 21 & 1.9 & 27 & 2.0 & 33 & 2.6 & 39 & 2.1 & 45 & 2.1
\end{tabular} \begin{tabular}{llllll|ll|lll|llll|ll}
4 & 2.2 & 10 & 2.0 & 16 & 3.2 & 22 & 1.8 & 28 & 2.9 & 34 & 2.4 & 40 & 3.3 & 46 & 3.4
\end{tabular}

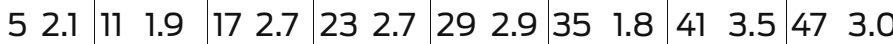
\begin{tabular}{lll|l|ll|ll|ll|ll|ll|ll}
6 & 1.5 & 12 & 1.7 & 18 & 2.2 & 24 & 3.0 & 30 & 2.7 & 36 & 1.7 & 42 & 3.5 & 48 & 2.9
\end{tabular}

Vi kan sortere datasettet ved hjelp av «stamme-og-blad»-metoden (stem-andleaf plot) (figur 1). Vi deler datasettet inn i hensiktsmessige, like intervaller, og noterer hver registrering:

Figur 1.

Lh (IE/L) målt hvert hos NN hvert

10. minutt

\section{Stamme-og-blad-plott}

\begin{tabular}{|c|c|}
\hline 14 & $\theta \theta \Theta$ \\
\hline 16 & $\theta \theta$ \\
\hline 18 & 000000 \\
\hline 20 & $\theta 0 \theta 0 \theta \theta$ \\
\hline 22 & $\theta 0000000$ \\
\hline 24 & $\theta 000 \Theta$ \\
\hline 2 & $\theta 0000 \theta$ \\
\hline & $\theta \theta \theta$ \\
\hline & $\theta \theta \theta$ \\
\hline & $\theta 0 \theta$ \\
\hline & $\theta \theta \theta$ \\
\hline
\end{tabular}

Kommaet blir tatt bort. (Her ligger det et siffer til venstre for den loddrette streken.) De tre minste målingene er 1.4, $1.5 \mathrm{og} 1.5$, ikke 14.0 tre ganger, som en kan forledes til å tro. Vi ser området for målingene, og hvordan dataene fordeler seg. Vi kan anslå gjennomsnittet noenlunde. Men: plottet kan være misvisende.

Alternativt kan vi beskrive målingene ved hjelp av et boksdiagram. (Navnet er morsommere på engelsk: «box-andwiskers-plot»; - «kasse-og-værhår -diagram»).

\section{Figur 2.}

Lh (IE/L) hos NN målt hvert 10. minutt

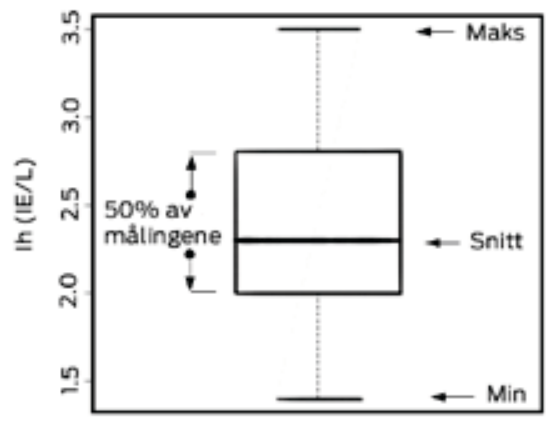

Boksdiagrammet inneholder mye informasjon. Vi ser området, gjennomsnittet, og min- og maksverdiene. Boksen inneholder de midterste 50 prosent av målingene (dvs. fra 25. til 75. percentil). Hadde vi hatt en sterkt avvikende verdi, ville denne vært angitt som en liten sirkel eller ei stjerne «utenfor» værhåra.

Figur 3.

Lh (IE/L) hos NN målt hvert 10. minutt

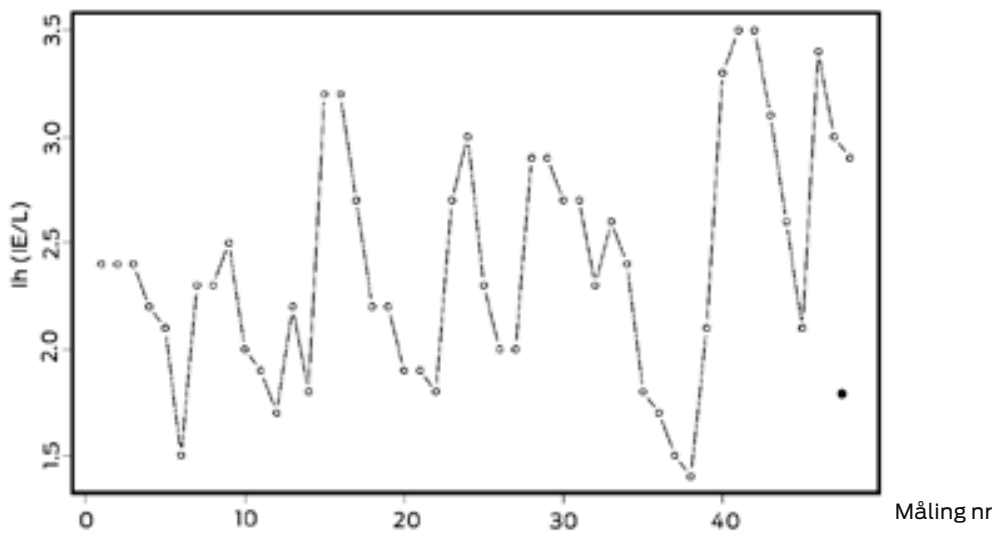

Målingene er foretatt med 10 minutters mellomrom. Slike målinger kalles tidsserier. Plotter vi målingene i den rekkefølgen de er gjennomført, vil svingningene i konsentrasjon komme fram.

Stamme- og bladplottet sorterer informasjonen fra «minst» til «størst». Dette kan være misvisende, om det ikke gjøres kjent. Statistiske figurer skal oppsummere den vesentlige informasjonen. Informasjonen skal være tydelig, korrekt og komplett. Man skal ikke trenge å lese artikkelen. Figuren eller tabellen skal forstås allikevel.

En kan gjerne kombinere flere figurer, eller figurer og tabeller. Når en skal lage slike, gjelder regelen «jo enklere, jo bedre». En bør bruke minst mulig overflødig informasjon, som farger, tredimensjonale stolper, skraveringer osv. Hvert element skal være nødvendig. Dette gjelder overskrifter, betegnelser på aksene, måleenheter, og selve grafikken.

Tabeller skal også ha minst mulig «krimskrams». Mange institusjoner og tidsskrifter har detaljerte normer for hvordan tabeller og figurer skal utformes. Dessverre varierer normene. Normene til «American Psychological Association» benyttes mye. Se «Publication Manual of the American Psychological Association» 6.th Ed., eller nettsida deres: http://www. apastyle.org for detaljer. IIII 